J. Perinat. Med. 15 (1987) 469

\title{
Surfactant substitution in the newborn by application of artificial surfactant
}

\author{
Colin John Morley \\ Department of Pediatrics, University of Cambridge, UK
}

Surfactant treatment is given on the assumption that surfactant deficiency is the major cause of respiratory distress syndrome (RDS). However, we know that babies with RDS are also very immature. They have a number of interrelated problems which are difficult to separate from surfactant deficiency: difficulty clearing their lung fluid; their lung structure is very immature; they have a patent ductus arteriosus with relative pulmonary hypertension and pulmonary hyperperfusion; their muscle tone is poor and their ribs are soft; they have erratic respiratory control which is prone to apnoea; surfactant is present but in reduced amounts with poor physical properties and there is often a massive leak of protein on to the alveolar surface which interferes with the surfactant function. It is important to remember that surfactant is only one of these problems and therefore surfactant therapy cannot be expected to cure RDS although it may reduce the severity of some of the symptoms.

In 1977 we synthesized an artificial lung surfactant composed of dipalmitoylphosphatidylcholine and unsaturated phosphatidylglycerol, called ALEC standing for artificial lung expanding compound $[1-3,6]$. This has physical properties similar to natural surfactant when used in a crystalline state and applied to an air-water interface, in excess, at $37^{\circ} \mathrm{C}$. We initially tested this artificial surfactant by measuring the compliance of artificially ventilated 27 day fetal rabbits comparing the effect with untreated controls and animals treated with natural rabbit surfactant extract [8] (figure 1). After 30 minutes ventilation the compliance was higher in both treated groups than the controls but highest in the natural surfactant group. However, by 60 minutes both natural and artificial surfactant treated groups had similar values.

\section{Curriculum vitae}

COLIN JOHN MORLeY was born in 1943. From 1963 to 1968 he studied medicine at the University of Cambridge and was graduated in 1968. Since 1979 he has been a lecturer in the University of Cambridge. His research interests include surfactant therapy, techniques of neonatal ventilation, sudden infant death syndrome.

Encouraged by this result, the physical properties of the surfactant and its lack of potentially toxic components, we started using the artificial surfactant in premature babies. This was used in a study between September 1979 and January 1982 as one $25 \mathrm{mg}$ dose of powder given to resuscitated babies at birth down the endotracheal tube $[5,7]$. It was a non-randomized, case controlled, study eventually involving 129 babies under 35 weeks gestation. The control babies had a mortality of $19 \%$ compared qith $4 \%$ of the surfactant treated babies.

Encouraged by this result, in January 1982 between Cambridge and Nottingham we started a

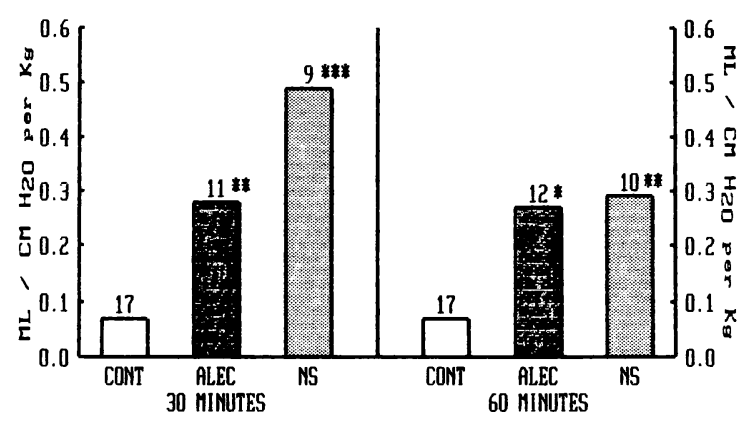

Figure 1. Lung-torax compliance during artificial ventilation; 27 day fetal rabbits. 
randomized controlled trial with 360 babies under 34 weeks gestation to study the prophylactic effect of ALEC suspension given at birth on respiratory support and compliance during the first few days of life. Babies were unselected and born in one of the hospitals under 35 weeks gestation. They were randomized to surfactant or control just before birth. ALEC powder, 50 to $100 \mathrm{mgs}$ was hand shaken with $1 \mathrm{ml}$ saline at $4{ }^{\circ} \mathrm{C}$ just before delivery. Specimens were obtained for subsequent $\mathrm{L} / \mathrm{S}$ ratio analysis. One $\mathrm{ml}$ of saline was the control substance. Surfactant or saline were placed in the pharynx at birth. If the baby was intubated further doses were given down the endotracheal tube at 10 minutes 1 hour and 24 hours. Trial treatment was not disclosed to the clinical teams. Compliance of the respiratory system was measured where possible at 1, 6, 24, 48 hours and 7 days. Randomized babies were excluded from the analysis if they were stillborn or had gross malformations. The trial was analyzed by treatment as randomized.

The factors which influence the outcome of premature babies are shown in table I. Three hundred and forty-one unselected babies were entered into the trial. Fourteen were ineligible because they were stillborn or had major malformations. There were 163 surfactant treated and 164 controls, 69 were surfactant treated babies and 67 were controls were under 30 weeks gestation. The data for babies under 30 weeks gestation are shown separately or in brackets. The two groups are reasonably well matched.

In this trial there was no apparent effect from surfactant treatment in babies of 30 weeks gestation or more. This is because the incidence of RDS and its complications were very low, only $1 \%$ have an IVH, PDA or die. Two thirds are in oxygen for under 24 hours and $75 \%$ are not ventilated. Therefore the results shown are for the babies under 30 weeks gestation.

Compliance of the respiratory system was measured at the bedside using an oesophageal balloon for dynamic compliance or ventilator pressure for static compliance, and a pneumotachograph in an endotracheal tube or facemask. Figure 2 shows compliance measurements for babies under 30

Table I. Basic data and factors which might influence outcome; shown as percentages or mean and standard deviation; Data for babies of $<30$ weeks gestation are given in brackets or separately.

\begin{tabular}{|c|c|c|c|c|}
\hline & \multicolumn{2}{|c|}{ Surfactant } & \multicolumn{2}{|l|}{ Controls } \\
\hline Number of babies & \multicolumn{2}{|l|}{$170(71)$} & \multicolumn{2}{|l|}{$171(70)$} \\
\hline Ineligible & \multicolumn{2}{|l|}{$7(2)$} & \multicolumn{2}{|l|}{$7(3)$} \\
\hline Eligible & \multicolumn{2}{|l|}{$163(69)$} & \multicolumn{2}{|l|}{$164(67)$} \\
\hline Randomized in Cambridge & \multicolumn{2}{|l|}{$138(61)$} & \multicolumn{2}{|l|}{$138(61)$} \\
\hline \multicolumn{5}{|l|}{ Eligible babies } \\
\hline Birth weight & \multicolumn{2}{|c|}{$1426.0 \pm 434$} & \multicolumn{2}{|c|}{$1423.0 \pm 448$} \\
\hline Birth weight $<30$ weeks & \multicolumn{2}{|c|}{$1092.0 \pm 229$} & \multicolumn{2}{|c|}{$1047.0 \pm 270$} \\
\hline Gestational age & $29.9 \pm$ & 2.6 & $29.8 \pm$ & 2.6 \\
\hline Gestational age $<30$ weeks & $27.4 \pm$ & 1.7 & $27.4 \pm$ & 1.6 \\
\hline $\mathrm{L} / \mathrm{S}$ ratio* & $1.7 \pm$ & 0.58 & $1.7 \pm$ & 0.58 \\
\hline L/S ratio** $<30$ weeks & $1.7 \pm$ & 0.60 & $1.7 \pm$ & 0.59 \\
\hline Males & \multicolumn{2}{|c|}{$50 \%(57 \%)$} & \multicolumn{2}{|c|}{$54 \%(61 \%)$} \\
\hline Membrane rupture $>2$ days & \multicolumn{2}{|c|}{$19 \%(23 \%)$} & \multicolumn{2}{|c|}{$19 \%(22 \%)$} \\
\hline Pre-eclampsia & \multicolumn{2}{|c|}{$17 \%(14 \%)$} & \multicolumn{2}{|c|}{$22 \%(22 \%)$} \\
\hline Cesarian section & \multicolumn{2}{|c|}{$54 \%(51 \%)$} & \multicolumn{2}{|c|}{$57 \%(61 \%)$} \\
\hline Labor & \multicolumn{2}{|c|}{$68 \%(72 \%)$} & \multicolumn{2}{|c|}{$60 \%(61 \%)$} \\
\hline Mothers age $<20$ yrs & \multicolumn{2}{|c|}{$14 \%(14 \%)$} & \multicolumn{2}{|c|}{$14 \%(6 \%)$} \\
\hline Steroids & \multicolumn{2}{|c|}{$8 \%(10 \%)$} & \multicolumn{2}{|c|}{$6 \%(9 \%)$} \\
\hline Beta stimulants & \multicolumn{2}{|c|}{$25 \%(32 \%)$} & \multicolumn{2}{|c|}{$23 \%(34 \%)$} \\
\hline 2nd twin & \multicolumn{2}{|c|}{$9 \% \quad(7 \%)$} & \multicolumn{2}{|c|}{$17 \%(21 \%)$} \\
\hline
\end{tabular}

$\mathrm{L} / \mathrm{S}$ ratios were analyzed from amniotic or gastric aspirate collected at delivery.

* L/S ratios were analyzable only in 136 surfactant babies in 134 controls.

** L/S ratios were analyzable only in 59 surfactant babies and 54 controls. 


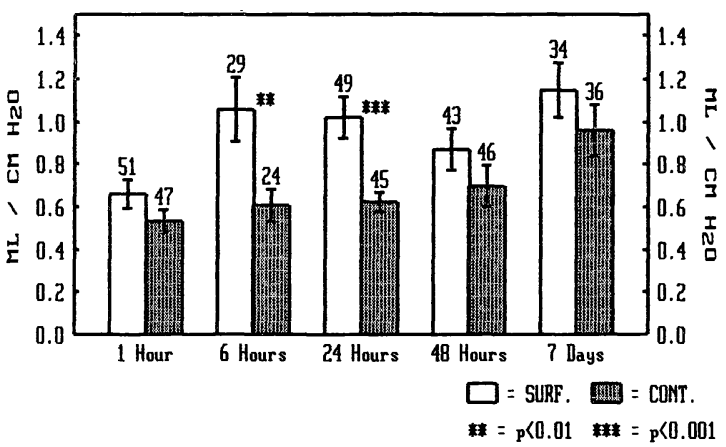

Figure 2. Compliance of the respiratory system - Cambridge - Nottingham trial ( $<30$ weeks).

weeks gestation made at 1, 6, 24, 48 hours and 7 days. The error bars are standard error of the mean. The open bars represent surfactant therapy and the speckled bars controls. The numbers are the numbers of babies measured at each time. There is little effect at 1 hour, but significant improvements in the surfactant treated group at 6 and 24 hours. At 48 hours and 7 days the compliance is higher but the difference is not significant. The compliance of the surfactant treated babies rose rapidly in the first 6 hours to a plateau whereas the controls improved slowly over the first few days.

Figure 3 shows the inspired oxygen concentrations for the two groups of babies under 30 weeks gestation over the first 4 days of life. Note the scale on the bottom is not linear and the error bars are standard error of the mean. It is presented in this way to be comparable to the data of ENHORNING [8]. It shows that from 6 hours the surfactant treated babies had inspired oxygen requirements significantly lower than the controls.

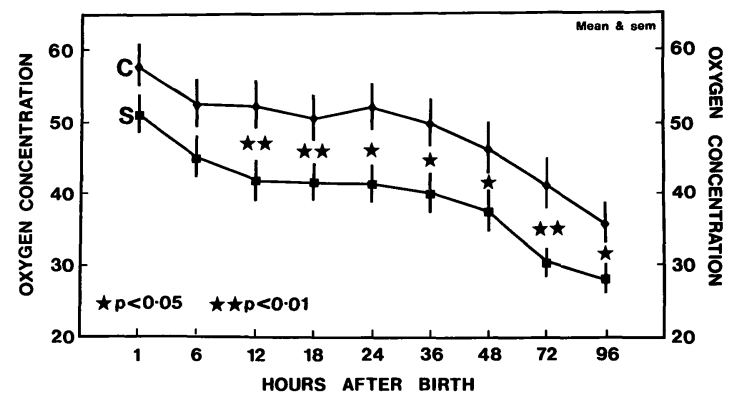

Figure 3. Average inspired oxygen concentrations for all the babies under 30 weeks gestation.

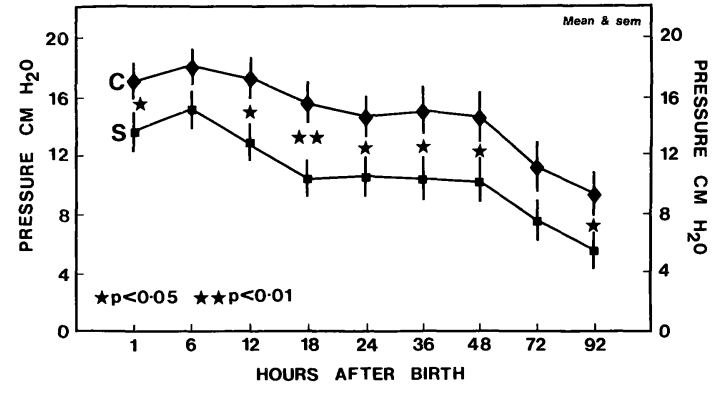

Figure 4. Average peak ventilator pressure for all the babies less than 30 weeks gestation.

Figure 4 shows the peak inspiratory pressures for the two groups of babies under 30 weeks gestation over the first 4 days of life. Note the scale on the bottom is not linear and the error bars are standard error of the mean. It shows that from 12 hours the surfactant treated babies had peak inspiratory pressures significantly lower than the controls.

Table II shows the incidence of complications for babies under 30 weeks gestation. They are patent ductus arteriosus, pneumothorax, death at any time while in the neonatal intensive care unit, the need for oxygen therapy longer than 28 days, the use of paralyzing agents during ventilator therapy and periventricular hemorrhages. It shows the numbers in each group and the percentage of each complication with $\mathbf{9 5 \%}$ confidence intervals for the difference between the two groups. There was no significant difference in the incidence of patent ductus arteriosus or pneumothorax. The mortality for the surfactant treated babies was significantly reduced from $34 \%$ to $19 \%$. That is 15 less deaths per 100 babies. The $95 \%$ confidence interval is wide with a possible effect of a reduction of 1 death to 31 fewer deaths per 100 babies. When considering the incidence of all other complications it must be remembered that more surfactant treated babies survived to be at risk of the complication.

There was a significant reduction in the number of surfactant treated babies receiving prolonged oxygen therapy. This effect was equivalent to 18 less babies per 100 with $95 \%$ confidence intervals of 3 to 33 less receiving oxygen beyond 28 days.

The use of pancuronium was considered to be a complication of RDS because babies with the 
Table II. Complications of prematurity babies < 30 weeks; incidence, mean and $95 \%$ confidence interval for the difference.

\begin{tabular}{|c|c|c|c|c|}
\hline Complication & $\begin{array}{l}\text { Controls } \\
\mathrm{N}=67\end{array}$ & $\begin{array}{l}\text { Surfactant } \\
\mathrm{n}=69\end{array}$ & $\begin{array}{l}\text { Difference per } 100 \text { treated babies } \\
\text { (mean and } 95 \% \mathrm{Cl} \text { ) }\end{array}$ & $\mathrm{p}$ \\
\hline Deaths in the NICU ${ }^{1}$ & $34 \%$ & $19 \%$ & $1-15-31$ & 0.05 \\
\hline $\mathrm{IVH}^{2}$ & $40 \%$ & $19 \%$ & $6-21-36$ & 0.006 \\
\hline Oxygen $>28$ days $^{3}$ & $35 \%$ & $20 \%$ & $0-15-30$ & 0.05 \\
\hline Pneumothorax & $36 \%$ & $28 \%$ & $\begin{array}{lll}-7 & -1\end{array}-32$ & 0.3 \\
\hline Patent ductus ${ }^{4}$ & $28 \%$ & $26 \%$ & $-12 \longrightarrow 2-16$ & 0.8 \\
\hline \multirow[t]{2}{*}{ Pancuronium $^{5}$} & $52 \%$ & $27 \%$ & $7-25-43$ & 0.008 \\
\hline & & & -15 & \\
\hline
\end{tabular}

${ }^{1}$ include death from all causes; ${ }^{2}$ mainly diagnosed by ultrasound scan, but in babies who died early they were found at post mortem; ${ }^{3}$ is calculated as the incidence of 28 day survivors; ${ }^{4}$ diagnosed from clinical criteria; ${ }^{5}$ percentage of ventilated Cambridge babies (ALEC 48, Controls 54) who were paralyzed.

worst lung disease were paralyzed. The use of pancuronium in the surfactant treated babies was reduced from $52 \%$ to $27 \%$ a reduction of 25 per 100 babies with $95 \%$ confidence interval from 7 to 43 less babies being paralyzed. The incidence of all grades of periventricular hemorrhages was significantly reduced equivalent to 21 babies per 100 from $40 \%$ to $19 \%$ with confidence intervals showing a possible reduction from 6 less hemorrhages to 36 less hemorrhages per 100 babies.

Data on mortality: Babies die from a variety of causes, not all RDS. Eighty eight per cent ( 21 out of 24) of the controls died as a consequence of RDS compared with only $50 \%$ (7 out of 14) of the surfactant treated babies $(\mathrm{p}<0.05)$, showing that the reduction in mortality was particularly affecting RDS deaths.

Figure 5 shows the incidence of periventricular hemorrhages for Cambridge babies. Nottingham babies were not regularly scanned. It shows the number of babies with hemorrhages divided into subgroups. $\mathrm{E}$ is equivocal; 1 is germinal layer hemorrhage; 2 and 3 are hemorrhages contained within the ventricles; 4 is hemorrhage into the brain parenchyma and PM is parenchymal hemorrhage found at postmortem in babies who died before they could be scanned, the numbers of these are very small. The difference is significant overall and also for grade 4 hemorrhages separately.

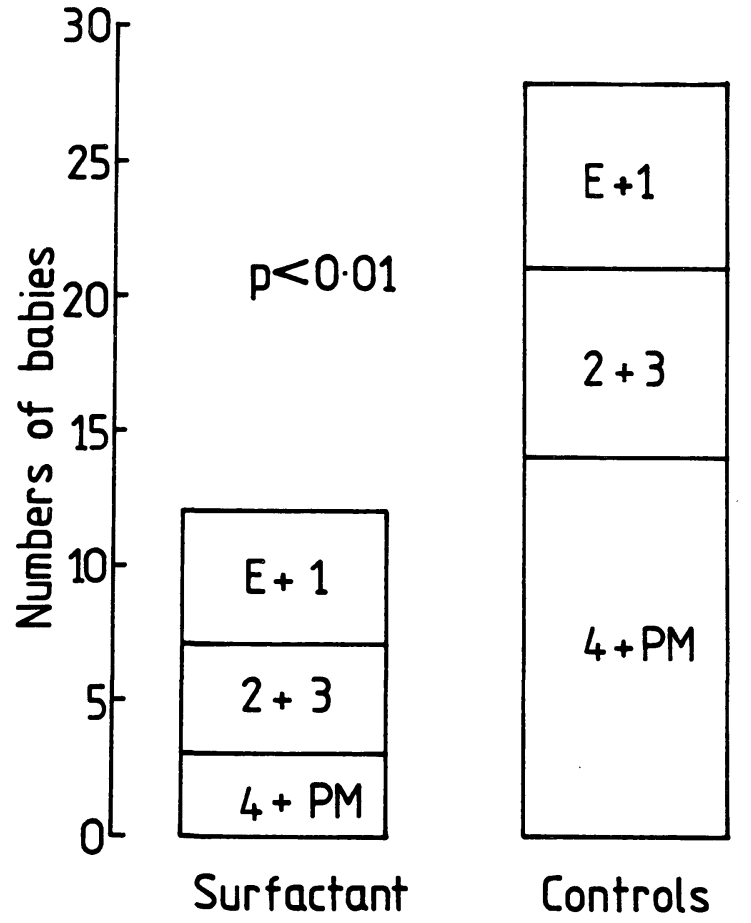

Figure 5. Periventricular hemorrhages diagnosed in the Cambridge subgroup. They are grouped according to the Papile classification: $\mathrm{E}=$ equivocal, 1 = grade 1 , $2=$ grade $2,3=$ grade $3,4=$ grade 4 and $P M=$ hemorrhage diagnosed at postmortem. The $p$ value is for the comparison of the numbers in the two groups. The statistical significance for the comparison of the numbers with grade 4 or PM is $\chi^{2}=6.268(\mathrm{p}<0.05)$. 
In May 1984 we started a second stage of this trial [9]. The purpose was to define the effect of artificial surfactant on the complications of prematurity in babies between 25 and 29 weeks gestation. Including babies of this gestation already randomized in the Cambridge-Nottingham trial approximately 300 babies were required to show a $25 \%$ reduction in mortality from $36 \%$ to $27 \%$ with a $75 \%$ power. This required collaboration from 10 British neonatal units to produce a quick result.

The protocol for this trial was almost identical to the Cambridge Nottingham trial. Babies entered the study if they were born in hospital between 25 and 29 weeks gestation. They were randomized to surfactant or control just before birth. Randomization was stratified by gestational age to prevent imbalance. The strata were 25 and 26 weeks and 27, 28 and 29 weeks. Approximately $100 \mathrm{mg}$ of surfactant powder suspended in $1 \mathrm{ml}$ of cold saline or $1 \mathrm{ml}$ of saline as the control substance were placed in the pharynx at birth. If the baby was intubated further doses were given down the endotracheal tube at 10 minutes 1 hour and 24 hours. The randomization and treatment were kept secrete. Babies were retrospectively excluded from the main analysis because they were stillborn, grossly malformed or not resuscitated. Analysis was for treatment groups as randomized.

Three hundred and twenty-eight babies were entered into the trial. There were 164 in each treatment group, 20 were ineligible. The factors which influence the outcome of premature babies are shown in table III. They are well matched between the groups particularly for birthweight, sex, labor, steroids and beta-adrenergic stimulants.

RDS is the major complication of prematurity. We developed a simple classification prior to the trial. It is based on the number of hours a baby receives more than $30 \%$ oxygen in the first 5 days. Babies receiving more than $30 \%$ oxygen for under 24 hours were defined as having no RDS. Babies receiving more than $30 \%$ oxygen for 25 to 48 hours had mild RDS. Babies in more than $30 \%$ oxygen for 2 to 5 days had moderate RDS and more than 5 days severe RDS. If a baby died in the first 5 days receiving more than $30 \%$ oxygen the RDS was graded severe.

Table III. Comparison of surfactant and control groups by gestational age strata for antenatal factors which might influence the outcome.

\begin{tabular}{|c|c|c|c|c|c|c|}
\hline & \multicolumn{2}{|l|}{ Overall } & \multicolumn{2}{|c|}{$25-26$ weeks } & \multicolumn{2}{|c|}{$27-29$ weeks } \\
\hline & ALEC & Control & ALEC & Control & ALEC & Control \\
\hline Number & 164 & 164 & 46 & 40 & 118 & 124 \\
\hline Ineligible & 5 & 15 & 3 & 8 & 2 & 7 \\
\hline Eligible & 159 & 149 & 43 & 32 & 116 & 117 \\
\hline \multicolumn{7}{|l|}{ For eligible babies } \\
\hline $\begin{array}{l}\text { Birth weight (gm) } \\
\text { (SD) }\end{array}$ & $\begin{array}{l}1093 \\
(310)\end{array}$ & $\begin{array}{l}1070 \\
(251)\end{array}$ & $\begin{array}{l}826 \\
(118)\end{array}$ & $\begin{array}{l}809 \\
(132)\end{array}$ & $\begin{array}{l}1192 \\
(300)\end{array}$ & $\begin{array}{l}1141 \\
(228)\end{array}$ \\
\hline Gestational age (weeks) & 27.6 & 27.6 & 25.7 & 25.5 & 28.3 & 28.1 \\
\hline (SD) & $(1.3)$ & $(1.3)$ & $(0.4)$ & $(0.5)$ & $(0.8)$ & $(0.8)$ \\
\hline Males & $51 \%$ & $54 \%$ & $72 \%$ & $59 \%$ & $43 \%$ & $52 \%$ \\
\hline Membrane rupture $>2$ days & $23 \%$ & $19 \%$ & $26 \%$ & $25 \%$ & $22 \%$ & $17 \%$ \\
\hline Pre-eclampsia & $17 \%$ & $21 \%$ & $16 \%$ & $13 \%$ & $17 \%$ & $23 \%$ \\
\hline Cesarian section & $58 \%$ & $62 \%$ & $44 \%$ & $38 \%$ & $63 \%$ & $69 \%$ \\
\hline Labor & $67 \%$ & $60 \%$ & $81 \%$ & $81 \%$ & $61 \%$ & $55 \%$ \\
\hline Steroids & $11 \%$ & $14 \%$ & $12 \%$ & $12 \%$ & $11 \%$ & $14 \%$ \\
\hline Beta stimulants & $26 \%$ & $32 \%$ & $35 \%$ & $50 \%$ & $23 \%$ & $27 \%$ \\
\hline Multiple birth & $19 \%$ & $29 \%$ & $21 \%$ & $31 \%$ & $19 \%$ & $28 \%$ \\
\hline IUGR & $15 \%$ & $15 \%$ & $16 \%$ & $3 \%$ & $15 \%$ & $19 \%$ \\
\hline Born infected & $4 \%$ & $6 \%$ & 7 & $9 \%$ & $3 \%$ & $5 \%$ \\
\hline
\end{tabular}

IUGR = intrauterine growth retardation

Born infected = A baby who had bacteria growing in a blood culture taken at delivery. 


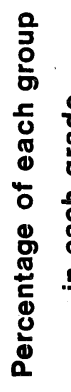

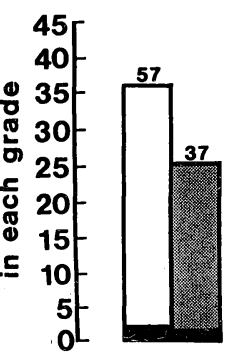

None

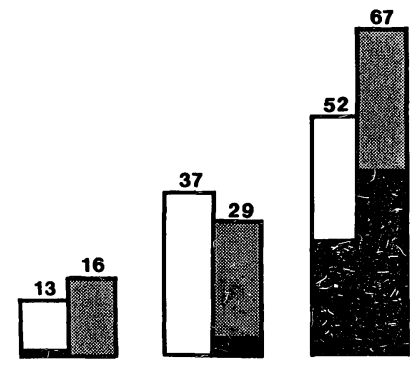

Mild Moderate

Severe
Figure 6. RDS subdivided into 4 grades of severity and shown as the percentage of ALEC or Controls in each grade. The ALEC treated are open and controls are stippled. The deaths in each grade are shown in black. The numbers of babies in each grade are shown above the block. For definition of RDS grades see the text. The $\chi^{2}$.test for trend on ordered severity $(0,1,2,3)$ is $4.84 \mathrm{p}<0.03$.

Figure 6 shows the RDS grades with the percentage of each treatment group in each grade. Surfactant treated babies are represented by the open bars and controls by the stippled bars. The deaths in each grade are shown white. The numbers above each bar are the numbers in each grade. There are 159 surfactant treated babies and 149 controls. In the No RDS grade there were over one third more surfactant treated babies than controls. In the severe grade there were $29 \%$ fewer surfactant treated babies. There is little difference between the groups in the two intermediate grades. An analysis for trend is significant at the 3\% level, showing the surfactant treated babies have less severe RDS.

Table IV shows the effect on hours of ventilation in the first 10 days using multiple regression analysis. The first ten days were chosen as the time when prophylactic ALEC treatment might have most effect on respiration. Only survivors were included even though more controls died. This therefore gives a conservative analysis. The parameters taken into account were surfactant, sex, gestational age, first or subsequent multiple births and non-Cambridge centers. The baseline was a control, male, singleton at 25 weeks gestation born in Cambridge. Such a baby has an average of 183 hours ventilation in the first 10 days. The coefficients can be added or subtracted from this value to show the effect of each parameter. Surviving surfactant treated babies had on average 20
Table IV. Effect of prognostic factors on hours of ventilation in the first 10 days survivors only.

\begin{tabular}{llll}
\hline $\begin{array}{l}\text { Prognostic } \\
\text { factor }\end{array}$ & Hours & IPPV & \\
\hline & coeff & $(\mathrm{se})$ & $\mathrm{p}$ \\
\hline ALEC & -20.2 & $(10.1)$ & $<0.05$ \\
Female & -2.1 & $(10.3)$ & $\mathrm{NS}$ \\
1 week GA & -31.4 & $(4.0)$ & $<0.0001$ \\
1st Multiple & -14.0 & $(16.0)$ & $\mathrm{NS}$ \\
2+ Multiple & 56.6 & $(15.0)$ & $<0.0002$ \\
Non-Cambridge & 30.5 & $(10.3)$ & $<0.003$ \\
\hline
\end{tabular}

Baseline* 183.4 hours

Multiple regression analysis giving coefficients and standard errors with significance value. 1 week GA. means the effect for each additional week of gestational age. The regression coefficients are the change in hours of support attributable to each prognostic factor in the first 10 days.

* Baseline = male, singleton, control, 25 weeks gestation in Cambridge.

hours less ventilation in the first 10 days than the controls. This was significant at the $5 \%$ level.

Table V shows the complications of prematurity in the two groups. They are: all deaths in the neonatal intensive care unit, deaths in the first 28 days of life, parenchymal brain hemorrhages detected ultrasonically, oxygen therapy for more than 10 days, pneumothorax or interstitial emphysema, and patent ductus arteriosus and infection. It shows the percentage for each treatment group with $95 \%$ confidence intervals for the difference in percentage points and the significance of that difference. The overall mortality for the surfactant treated babies was reduced from $30 \%$ of the controls to $19 \%$, an $11 \%$ point difference with a $95 \%$ confidence interval from 2 to 21 fewer deaths per 100 babies. The 28 day mortality was reduced from $27 \%$ to $14 \%$ in the surfactant treated babies, a $13 \%$ point reduction with $95 \%$ confidence interval from 4 to 22 fewer deaths per 100 babies. When considering the incidence of all other complications it must be remembered that more of the surfactant treated babies have survived to be at risk of the complication. The incidence of parenchymal brain hemorrhages was reduced from $24 \%$ to $16 \%$ a reduction of 8 percentage points with $95 \%$ confidence interval of 1 more to 17 less hemorrhages per 100 babies. All babies are in- 
Table V. Complications of prematurity in the eligible babies in the two groups; percentage and $95 \%$ confidence interval for the difference in the percentages with $\mathrm{p}$ values for the difference taking into account the four stata (see analyses).

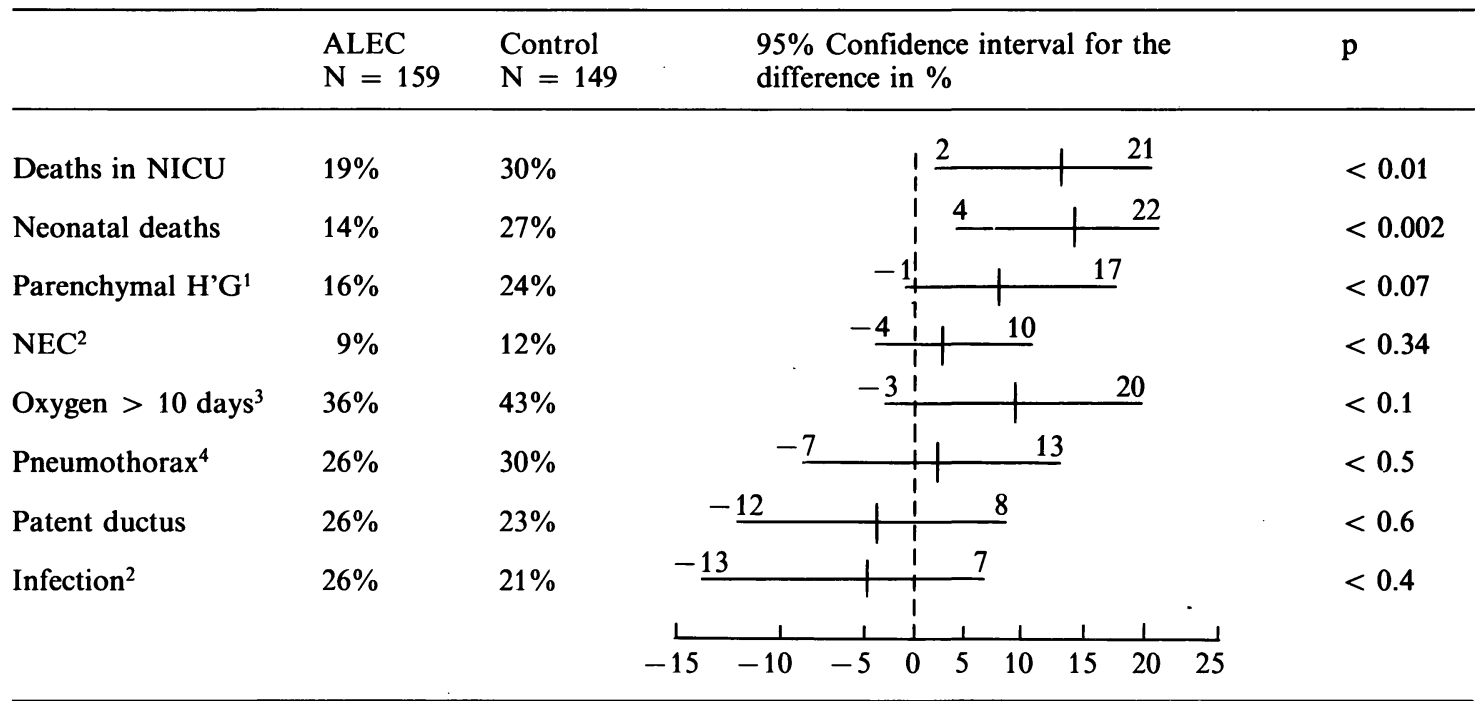

1 Five ALEC treated babies and 6 controls were not scanned therefore only 154 ALEC babies and 143 controls are included.

2 As defined serious postnatal infection was after the first 24 hours, NEC does not occur in the first 24 hours. The denominator for these was 152 ALEC treated babies and 139 controls.

3 There were 138 ALEC treated babies and 117 controls surviving 10 days.

4 Pneumothorax here refers to pneumothorax and interstitial emphysema.

cluded except for 5 surfactant treated and 6 controls who were not scanned. The incidence of other intraventricular and germinal layer hemorrhages was $19 \%$ in each group. Forty-three percent of surviving control babies received oxygen therapy for more than 10 days compared with $36 \%$ of surfactant treated babies. There was little difference in the incidence of pneumothoraces and interstitial emphysem, patent ductus arteriosus or infection.

We have now been studying the effect of artificial surfactant in premature babies under 35 weeks gestation since 1979. It has now been used at birth 12 large neonatal centers and 323 babies treated with 334 controls some randomized others not. The studies have consistently shown a reduced mortality. Overall there has been a significant reduction in mortality from $18.5 \%$ to $11 \%$ (p $<0.008$ ).
In conclusion, this artificial surfactant when given prophylactically reduces the severity of the RDS, the hours of ventilation and high inspired oxygen concentrations, the incidence of parenchymal brain hemorrhages and most significantly the mortality. It dies not appear to have any major harmful side effects.

I have concentrated on my own artificial surfactant data. However, there are other studies using mixtures of phospholipids, particularly from Professor OPLADEN which show similar results, that is RDS is not cured but the major complications are reduced. It is interesting that the clinical results from artificial surfactant treatment show very similar results to natural surfactant treatment when given at birth. I hope that the good results from all the different studies will mean that in the near future the outlook for very premature babies will be improved. 


\begin{abstract}
A protein-free artificial surfactant (ALEC) composed of two phospholipids when given as a prophylactic treatment at birth to very premature babies in randomized controlled trials. It was shown to reduce the severity of RDS, the ventilator pressure, the inspired oxygen
\end{abstract}

requirements, the compliance of the respiratory system, the neonatal mortality and the incidence of ventricular hemorrhage. There are no apparent side effects from this treatment.

Keywords: Dipalmitoyliphosphatidylcholine, intraventricular hemorrhage, neonatal mortality, phosphatidylglycerol, pneumothorax, premature infant, pulmonary surfactant, respiratory distress syndrome.

\section{Zusammenfassung}

\section{Substitution mit synthetischem Surfactant beim Neugebo- renen}

1977 wurde ein künstlicher Surfactant bestehend aus Dipalmitoylphosphatidylcholin und ungesättigten phosphorylierten Glycerolen mit der Bezeichnung ALEC synthetisiert. Zunächst wurde die Substanz bei künstlich beatmeten, 21 Tage alten Rattenfeten getestet. Dabei wurde gezeigt, daß die Compliance der Beatmungseinheit 30 und 60 Minuten nach Applikation signifikant verbessert war. Dann wurde eine fallkontrollierte Studie mit 129 Kindern unterhalb der 30. Schwangerschaftswoche durchgeführt und $25 \mathrm{mg}$ als Trockensubstanz in den Tubus gleich bei der Intubation post partum gegeben. In der Kontrollgruppe lag die Mortalität bei $19 \%$ verglichen mit $4 \%$ in der Surfactantgruppe.

Im Januar 1982 haben wir mit einer randomisierten Versuchsreihe, die 360 Kinder unterhalb der 34. Schwangerschaftswoche umfaßte, begonnen. Noch vor der Geburt wurden die Kinder der Surfactant- bzw. der Kontrollgruppe zugeordnet. Kurz vor der Entbindung wurde die Trockensubstanz in $1 \mathrm{ml}$ Kochsalz bei $4{ }^{\circ} \mathrm{C}$ aufgelöst; in der Kontrollgruppe wurde nur Kochsalz verwendet. Die Surfactantlösung bzw. das Kochsalz wurden bei Geburt in den Pharynx gegeben. Wurden die Kinder intubiert, gaben wir weitere Dosen nach $10 \mathrm{~min}, 1 \mathrm{~h}$ und $24 \mathrm{~h}$. Die Compliance der Beatmungseinheit wurde, wenn möglich nach 1 h, 6 h, 24 h, 48 h und $7 \mathrm{~d}$ gemessen. In der Versuchsreihe waren schließlich 163 mit Surfactant behandelte und 164 Kontrollkinder. Bei Kindern oberhalb der 30 . Woche zeigte sich kein Einfluß durch die Surfactantbehandlung; in dieser Gruppe traten ein RDS und dadurch bedingte Komplikationen sehr selten auf.

Von größerer Bedeutung ist die Surfactantbehandlung bei Kindern unterhalb der 30 . Woche. Hier war die Compliance des Beatmungssystems nach 6 bzw. $24 \mathrm{~h}$ deutlich besser. Der $\mathrm{O}_{2}$-Gehalt in der Einatmungsluft war in der Surfactantgruppe ab der 6. Lebensstunde signifikant niedriger. Ab der 12. Lebensstunde waren auch die Maxima beim Inspirationsdruck signifikant geringer. In bezug auf einen offenen Ductus arteriosus oder einen Pneumothorax gab es keine signifikanten
Unterschiede. In der Surfactantgruppe war die Mortalität von $34 \%$ auf $19 \%$ reduziert. Die Inzidenz von Ventrikelblutungen sank von $40 \%$ auf $19 \%$, und die Anzahl der Kinder, die länger als 28 Tage Sauerstoff benötigten, sank von $35 \%$ auf $20 \%$. Auch der Pancuroniumbedarf war in der Surfactantgruppe deutlich geringer.

Im Mai 1984 wurde der Versuch erweitert. Es sollte der Einfluß des synthetischen Surfactant auf die durch Frühgeburtlichkeit bedingten Komplikationen bei Kindern zwischen der 25 . und 29 . Woche bestimmt werden. 10 Zentren beteiligten sich. Abgesehen davon, daß jetzt nur Kinder zwischen der 25. und 29. Woche berücksichtigt wurden, war die Protokollierung mit der des ersten Versuchs identisch. Das Kollektiv umfaßte 328 Kinder. Bezüglich der Inzidenz eines RDS gab es deutliche Unterschiede; in der Kontrollgruppe betrug sie $36 \%$, in der Surfactantgruppe $25 \%$. Ein schweres RDS trat bei $45 \%$ der Kontrollkinder und bei $32 \%$ der Surfactantkinder auf. Die multiple Regressionsanalyse zeigte, daß die Anzahl der Kinder, die in den ersten 10 Lebenstagen beatmet werden mußten, nach Surfactantbehandlung deutlich reduziert war. In dieser multizentrischen Untersuchung war die neonatale Mortalität von $30 \%$ auf $19 \%$ reduziert; legt man die gesamten neonatalen Todesfälle zugrunde, gab es einen Abfall von $27 \%$ auf $14 \%$. Parenchymatöse Hirnblutungen sanken von $24 \%$ auf $16 \%$. Keine Unterschiede traten auf hinsichtlich eines Pneumothorax, eines offenen Ductus arteriosus und der Beatmungsdauer bei mehr als 10 Tagen.

Seit 1979 untersuchen wir nun den Einfluß von synthetischem Surfactant auf Frühgeborene unterhalb der 35. Woche. Die Substanz wurde in 12 großen neonatalen Zentren eingesetzt. 323 Kinder wurden mit Surfactant behandelt und mit 334 Kontrollkindern verglichen. Insgesamt wurde eine Senkung der Mortalität von $18.5 \%$ auf $11 \%$ erreicht.

Zusammenfassend senkt die prophylaktische Surfactantgabe den Schweregrad eines RDS, die Beatmungsdauer und die inspiratorische $\mathrm{O}_{2}$-Konzentration sowie die Inzidenz von Parenchymblutungen im Gehirn, die Mortalität und die Compliance des Beatmungssystems. Es sind keine ernsthaften Nebenwirkungen bekannt.

Schlüsselwörter: Dipalmitoylphosphatidylcholin, Frühgeborenes, intraventrikuläre Blutung, Lungensurfactant, neonatale Mortalität, Phosphatidylglycerol, Pneumothorax, RDS. 


\section{Résumé}

Substitution de surfactant chez le nouveau-né par application de surfactant artificiel

En 1977 a été synthétisé un surfactant artificiel composé de dipalmitylephosoptidy choline, un glycerol phosphorylé insaturé appelé ALEC. Ce surfactant artificiel a des propriétés similaires à celles du surfactant naturel. Il a été testé initialement chez des fotus se lapin de 27 jours ventilés artificiellement et à montré une amélioration significative de la compliance du système respiratoire à 30 et à 60 minutes. Le surfactant a été initialement utilisé dans une étude contrôlée comportant 129 nouveaux-nés de moins de 30 semaines de gestation à la dose unique de $25 \mathrm{mg}$ de poudre instillée dans la sonde d'intubation, à la naissance. Dans cette étude les enfants témoins ont eu une mortalité de $19 \%$ en comparaison d'une mortalité de $4 \%$ chez les enfants traités par surfactant.

En janvier 1982, une essai controlé randomisé concernant 360 enfants de moins de 34 semaines de gestation a été débuté. Les enfants étaient randomisés pour le surfactant ou comme témoin juste avant la naissance. La poudre de surfactant était mélangée à la main avec $1 \mathrm{ml}$ de sérum salé à $4{ }^{\circ} \mathrm{C}$ juste avant l'accouchement. Comme substance témoin $1 \mathrm{ml}$ de sérum salé était utilisé. A la naissance le surfactant ou le sérum salé était placé au niveau du pharynx. Si l'enfant était intubé d'autres doses étaient données à 10 minutes, une heure et à 24 heures. Si possible, la compliance du système respiratoire était mesurée à $1,6,24,48$ heures et 7 jours. Dans cet essai, il u a eu 163 enfants traités par surfactant et 164 témoins. Il n' y a pas eu des effets apparent secondaire au traitement par surfactant chez les enfants de 30 semaines de gestation ou plus car l'incidence du SDR et de ses complications est très faible dans ce groupe.

Tous les effets significatifs du traitement par le surfactant ont été observés chez les enfants de moins de 30 semaines. La compliance du système respiratoire a été améliorée de façon significative 6 heures et 24 heures après le traitement. La concentration d'oxygène inspiré était significativement inférieure dans le groupe d'enfants traités par surfactant dès 6 heures de vie. Le pic de pression inspiratoires était significativement inférieur dans le groupe traité par surfactant dès 12 heures de vie. Il n'y a pas eu de différence significative en ce qui concerne les canaux artériels patents et les pneumothorax. La mortalité du groupe surfactant a été significativement diminuée de $34 \%$ à $19 \%$. Il y a eu une réduction signifi- cative de la survenue d'hémorragies ventriculaires de $40 \%$ à $19 \%$. Le nombre d'enfant necessitant de l'oxygène pendant plus de 28 jours a été diminué de $35 \%$ à $20 \%$. Il y a également eu une réduction significative de l'utilisation de Pancuronium dans le groupe surfactant. En mai 1984, cet essai a été étendu à un essai de second ordre dont l'objectif était de définir les effets du surfactant artificiel sur les complications de la prématurité chez les enfants entre 25 et 29 semaines de gestation. Cet essai comprenait les enfants de 10 centres. Le protocole de cet essai était à peu près identique à l'essai précédent à l'exception du fait que les enfants entraient dans l'étude s'ils étaient entre 25 et 29 semaines de gestation. 328 enfants sont entrés dans cet essai. L'incidence du syndrome de détresse respiratoire a été significativement modifiée, avec $36 \%$ de témoin sans SDR en comparaison de $25 \%$ des traités par surfactant, de plus $45 \%$ des témoins ont présenté un SDR grave, contre $32 \%$ des enfants traités par surfactant. En utilisant une analyse à regressions multiples, le nombre d'heures de ventilation des enfants au cours des 10 premiers jours de vie a été significativement diminué par le traitement surfactant. Dan cet essai multicentrique, la mortalité néonatale a été diminuée de $30 \%$ à $19 \%$, le nombre total de morts néonatales de $27 \%$ à $14 \%$, l'incidence des hémorrhagies cérébrales parenchymateuses de $24 \%$ à $16 \%$. Il n'y a pas eu de réduction significative des penumothorax, ni des canaux artificiels patents ni de la durée d'oxygène de plus de 10 jours.

Nous sommes maintenant en train d'étudier l'effet du surfactant artificiel chez les prématurés de moins de $\mathbf{3 5}$ semaines depuis 1979. Il a maintenant été utilisé à la naissance dans 12 grands centres néonataux, 323 enfants ont été traités par le surfactant, en comparaison de 334 témoins. Les études ont montré de façon consistante une diminution de la mortalité. Globalement, la diminution de la mortalité est significative, elle passe de $18,5 \%$ à $11 \%$.

En conclusion, le surfactant artificiel lorsqu'il est fourni en prophylaxie, diminue la sévérité du SDR, le nombre d'heures de ventilation et la concentration d'oxygène inspiré, l'incidence des hémorrhagies cérébrales parenchymateuses, la mortalité et la compliance du système respiratoire. Il n'est pas apparu qu'il présente des effets secondaires nocifs majeurs.

Mots-clés: Dipalmitoyliphosphatidylcholine, hémorragie ventriculaire, mortalité néonatale, phosphatidylglycérol, pneumothorax, prématuré, surfactant pulmonaire, syndrome de détresse respiratoire.

Acknowledgements: I would like to acknowledge the contribution to all this work by Dr. A. BANGHAM, Mr NiGEL Miller, Dr. Anne Greenough, Dr. Sheila Gore, Dr Charles Hill Professor John Davis and the Neonatologists in Aberdeen, Birmingham, Edinburgh, Glasgow, King's College Hospital, London, Liverpool, Newcastle St. Georges's Hospital, London, and Leeds and Nottingham. The work has been supported by the Medical Research Council, Action Research and the University of Cambridge Baby Research Fund. 


\section{References}

[1] BANGHAM AD: Breathing made easy. New Scientist 85 (1980) 408

[2] Bangham AD, NGA Miller, RJ Davies, A GreeNOUGH, CJ MORLEY: Introductory remarks about Artificial Lung Expanding Compounds (ALEC). Colloid and Surfaces 10 (1984) 337

[3] Bangham AD, CJ Morley, MC Phillips: The physical properties of an effective lung surfactant. Biochim Biophys Acta 573 (1979) 552

[4] Enhorning G, A Shennan, F Possmayer, M Dunn, CP ChEn, J Milligan: Prevention of neonatal respiratory distress syndrome by tracheal instillation of surfactant. A randomized clinical trial. Pediatrics 76 (1985) 145

[5] MoRLEy CJ: The Cambridge experience of artificial surfactant. In: Strang L (ed): Proceedings of the International Symposium on the Physiology and Pathophysiology of the Fetal and Neonatal Lung. M. T.P. Ltd UK, Lancaster 1987
[6] Morley CJ, AD Bangham, P Johnson, GD ThorBURN, G JENKIN: Physical and physiological properties of dry lung surfactant. Nature 271 (1978) 162

[7] Morley CJ, AD Bangham, N Miller, JA Davis: Dry artificial surfactant and its effect on very premature babies. Lancet i (1981) 64

[8] Morley C, B Robertson, B Lachmann, R NilsSON, A Bangham, G GrossmanN, N Miller: Artificial surfactant and natural surfactant. Comparative study of the effects on premature rabbit lungs. Arch Dis Child 50 (1980) 758

[9] Ten Centre Study Group: Ten Centre trial of artificial surfactant (artificial lung expanding compound) in very premative babies. Br Med J 294 (1987) 491

\section{Colin J. Morley}

University Lecturer

Department of Pediatrics

University of Cambridge Clinical School

Addenbrooke's Hospital

Hills Road

Cambridge CB2 2QQ, U.K. 